\title{
Introduction: What Is Intercultural Dialogue and Why It Is Needed in Europe Today?
}

\begin{abstract}
The authors introduce the concept of intercultural dialogue and how it has been utilized as a policy by the Council of Europe and the European Union since the early 2000s. First, we explore intercultural dialogue's relation to and differences from other concepts commonly used to describe different stances in the governance of diversity, ranging from assimilation to integration and from multiculturalism to interculturalism. These different conceptual stances are contextualized by exploring the recent transformations in Europe and their impact on the political aims, goals, and discourses of the Council of Europe and the European Union. Second, we review the previous research on the concept of intercultural dialogue and discuss the criticism of the concept and its meaning and uses in policy discourses.
\end{abstract}

Keywords Intercultural dialogue $\bullet$ Interculturalism $\bullet$ Multiculturalism - Assimilation • Integration

There is an increasing need for a respectful cultural encounter, mutual understanding, and constructive dialogue in today's pluricultural, but polarized, Europe. This book is motivated by the current condition of European societies that have transformed quickly during the past decades due to global cultural flows, the influence of social media on culture and communication, and the forced and voluntary movement of people to and 
within Europe. While Europe has become an increasingly diverse continent where many people simultaneously identify with multiple different cultural and social groups, monoculturalist views and cultural purism have also struck back in many cultural contexts, (social) media, and political debates. European societies have faced a rise in populist, nationalist, and extremist movements that have incited xenophobic, anti-immigration, racist, anti-Semitic, and Islamophobic political attitudes and actions, as well as a selective defence of 'us' as a monocultural group. Attacks motivated by extremist ideologies have influenced people's views and notions of Europe and how to build its future.

European societies have commonly recognized cultural pluralization as a richness that, however, entails diverse challenges if cultural encounter is not based on mutual respect and an interest in understanding differences. The recent transformations in Europe are transnational, and prejudiced attitudes to and intolerance of differences present challenges to the whole continent; therefore, they have to be addressed also at the European level. The continent's core international organizations - the Council of Europe and the European Union-have sought to respond to the challenges that diversification and a lack of interest in understanding differences may entail by promoting policies that engender inclusion, tolerance, and respect for diversity. The ultimate goal of these policies is to strengthen social cohesion in inclusive societies. During the past decade, intercultural dialogue has been a core policy instrument in these attempts-commonly repeated in the policy discourses of the Council of Europe and the European Union.

Education is a key sector through which inclusion, tolerance, and respect for diversity can be advanced. It is, however, a profoundly national sector with distinct national education acts, policies, and curricula. The Council of Europe and the European Union have actively sought to impact on this sector through their conventions, declarations, policy recommendations, programmes, and projects aimed at children and young people, including educating them to encounter cultural differences. This book focuses on the education policies of these two European organizations and how they address, give meanings to, and utilize the concept and idea of intercultural dialogue in their education policy discourses.

Intercultural dialogue has been approached in previous research as a practice connected to various social and societal domains in contemporary societies. Scholars have explored diverse practices of intercultural dialogue, 
for example in intercultural education (e.g. Portera 2008; O'Grady 2010; Kowalczyk 2011; Ganesh and Holmes 2011; Zay 2011; Besley and Peters 2012; Štrajn 2018); intercultural communication (e.g. Houghton 2009; Hoskins and Sallah 2011; Ganesh and Holmes 2011); governing of diversities (e.g. Wiesand et al. 2008; Wilk-Wós 2010; Lähdesmäki and Wagener 2015); and art and urban design in today's culturally diverse environments (e.g. Wood and Landry 2008; Sandercock and Attili 2009; Leikkilä et al. 2013; Gonçalves and Majhanovich 2016). Intercultural dialogue has also been broadly discussed in academia in relation to the debate between multiculturalism and interculturalism-briefly explored later in this chapter. The previous research still lacks an in-depth examination of the complex meanings intertwined with the conceptualization of intercultural dialogue in education policies at the European level. This kind of conceptual analysis is needed since intercultural dialogue has become an ideal commonly repeated in various contexts in Council of Europe and European Union policy discourses. Moreover, the meanings of several other concepts commonly used in connection with intercultural dialogue in these discourses, such as identity, culture, heritage, and diversity, may remain vague, so these concepts may serve as rhetorical tools to promote diverse political goals beyond intercultural dialogue as such (see Wagener 2012; Lähdesmäki and Wagener 2015).

In addition to broadening the scope of previous research on intercultural dialogue by scrutinizing the policy discourses of the Council of Europe and the European Union, our aim is to offer a new methodological approach to the topic. Our research is firmly grounded in the practical application of in-depth concept analysis. In this book, we scrutinize how, and with what effect, intercultural dialogue-and the diverse concepts through which it is defined, explained, and discussed - is dealt with in the education policy documents of the Council of Europe and the European Union (hereinafter the European education policy documents). We approach concepts in these policy documents as 'actants' that generate meanings for the idea of intercultural dialogue and simultaneously either explicitly or implicitly frame a set of values related to it, construct the actors whom it concerns, and guide and govern the action included in it. Through an in-depth concept analysis, our research reveals the kinds of ideologies and political goals related to and beyond intercultural dialogue that are included in the policy discourses within the Council of Europe and the European Union. 
Our book is structured into six chapters, of which this introduction explores intercultural dialogue's relationship with other concepts commonly used to describe different stances in the governance of diversity. These different conceptual stances are contextualized by exploring the recent transformations in Europe and their impact on the political aims, goals, and discourses of the Council of Europe and the European Union. The introduction is followed by a detailed description of our method, our data, and the character of the Council of Europe and the European Union as promoters of intercultural dialogue and creators of policy documents regarding it. Our analysis is divided into three chapters. In the first one, we focus on the explicit meanings of intercultural dialogue in European education policy documents and how these meanings are both explicitly and implicitly produced in relation to other concepts and terms. This includes an in-depth analysis of the occurrences, co-occurrences, and thematic overlapping of these concepts. In the second analysis chapter, we focus on analysing 'densities' of interrelated concepts in policy documents. We scrutinize instances in the documents where many of the core concepts of intercultural dialogue appear in clusters. Our third analysis chapter brings a novel theoretical twist to the concept analysis of education policy rhetoric. In it, we discuss the 'politics of affect', as our conceptual approach includes an examination of affective rhetoric in general, and in particular of the affective nature of concepts used in the European education policy documents.

At the time of writing, a decade after the leading European politicians declared that multiculturalism had failed, a decade after the Council of Europe and the European Union started to actively promote intercultural dialogue as a response to this 'failure', and a decade after the differences and similarities between multiculturalism and interculturalism have been debated in academia, it is time to critically review the European policy documentation on intercultural dialogue and the meanings of the concept constructed in it. Our aim is to rethink the concept of intercultural dialogue and explore how policies regarding it could be developed. The final chapter of the book provides suggestions for improving future policies to better encompass the concerns connected to the lack of dialogue in a pluricultural and increasingly diversified, but also polarized, Europe. Lastly, we introduce a new conceptual tool-cultural literacy-to enhance intercultural dialogue in education in practice. 


\section{Contexts for Intercultural Dialogue In Today's Europe}

In the 2000s, Europe - as a part of a globalized world—has faced various challenges ranging from climate change to humanitarian tragedies, and from political turbulences and extremist attacks to social adversities within, at, and beyond its borders. Moreover, the European Union has been struggling with diverse crises-as political and media discourses in Europe have called them - that have impacted on European societies and their current politics. These interrelated crises range from the economic crisis of the eurozone and European financial markets to diverse political crises stemming from the so-called legitimation and democratic deficits of the European Union and the increase of Eurosceptic political parties seeking to exit the eurozone and/or the Union. The recent 'refugee crisis' has impacted on the political crises in the European Union, as the political actors in the Union and its member states have contradictory views on how to respond. Instead of as a 'refugee crisis', scholars have approached these intertwined challenges as Europe's border crisis (Vaughan-Williams 2015) or racial crisis (De Genova 2018). Moreover, and as closely related to all other challenges and crises, scholars have long perceived that the European Union is struggling with an identity crisis (e.g. Hoffmann 1994; Weiss 2002; Jenkins 2008). This identity crisis focuses on a difficulty to define what Europe is, what and who belongs to it, who Europeans are, and which elements a European identity or identities could or should be based on a Europe full of diverse political, material, and symbolic divisions and distinctions (Jenkins 2008; Lähdesmäki et al. 2020). The Council of Europe and the European Union have sought to respond to these intertwined challenges and crises in Europe by advancing the idea of unity and a new European narrative-along with respect and tolerance for diversity - and by enhancing both symbolic and concrete integration in and of European societies (Lähdesmäki 2016; Lähdesmäki et al. 2020).

Besides the Council of Europe and the European Union, various populist and radical right movements and parties around Europe have been interested in contributing to the European narrative and unity in Europe from their exclusive ideological bases. Besides 'the national', these movements and parties commonly identify with European roots and inheritance, particularly when they feel threatened by non-European others - immigrants from the Middle East, Africa, and Asia (see Lähdesmäki 2015, 2019; Brubaker 2017; Kaya and De Cesari 2019). 
Interpretations of the European past and narratives of its present and future are tools utilized by all parties across the political spectrum. All of them seek to advance what they see as best for the people. In populist and radical right movements and parties, the 'discourse of the people' (see Hellström 2006; Mudde 2007) plays a particular role: either explicitly or implicitly, it constructs the idea of the nation. Mudde $(2017,4)$ has emphasized that one of the ideological cornerstones of populism is nativism, which he defines as

an ideology that holds that states should be inhabited exclusively by members of the native group (the nation), and non-native (or alien) elements, whether persons or ideas, are fundamentally threatening to the homogeneous nation-state.

Nativism as an ideology combines nationalism and xenophobia. It links and lays the groundwork for diverse discriminative attitudes and practices among European populist and radical right parties, such as white supremacism, welfare chauvinism, misogyny, and homophobia. The emphasis on generational ties, ancestral roots, and 'bloodlines' presents the nation as a container, as a family to which one has access and belongs by birth (Norocel 2013; Wodak 2015, 76-77). In this ideology, the nation means a limited and sovereign community that exists and persists through time and is tied to a specific territory (space), inherently and essentially constructed through in/out opposition (Wodak 2015, 76-77). The populist and radical right parties' objection to the European Union and its integration stems from this nativist ideology. For these parties, the promotion of a pluralistic model of society and supranational institutions and political actors in Europe represents an attempt to destroy nations and the 'natural' order of nationalism, and thereby a sense of belonging and identity (Betz and Johnson 2004).

The fervour for national identities among the radical right and in populist parties, and their xenophobic, anti-immigration, racist, anti-Semitic, and Islamophobic political attitudes and actions have been explained from various social, socio-economic, and psychological points of view that do not require further discussion here. What is more relevant for this book is to understand the recent challenges and crises in Europe not as reactive to a 'chaotic European reality' but as proactive. Challenges and crises must be tackled and new policies created to respond to the transformed conditions. As Jenkins (2008) claims regarding the European Union, challenges, 
crises, and a lack of consensus enable and justify attempts to increase stability and consensus in and by the Union. For him, the lack of consensus on the idea of Europe is not a state of emergency in the European Union, either, but rather normality that may even be a source of its strength. Similarly, Eder (2014) notes how diverse crises, stemming from the problems with political, economic, and structural systems of the European Union, create opportunities to invent a European community in a new way.

The emphasis on intercultural dialogue in the Council of Europe and the European Union can be interpreted as an attempt to increase stability in Europe and to create a new narrative about European community and communality (see also Wilk-Wo's 2010). This attempt has motivated the European Union's recent idea to work jointly towards a European Education Area. In the European Commission's communication titled Strengthening European Identity through Education and Culture this work is justified as follows:

When our European values and democracies are tested by awakening populist forces at home and abroad or by the spreading of 'fake news' and the manipulation of our information networks, it is the moment when European Leaders and the EU institutions must react. (EC 2017,2)

Quoting the president of the Commission Jean-Claude Juncker, the communication declares:

Education and culture are the key to the future- both for the individual as well as for our Union as a whole. It is how we turn circumstance into opportunity, how we turn mirrors into windows and how we give roots to what it means to be 'European', in all its diversity. (EC 2017, 1)

Even though diverse tensions, confrontations, and controversies between population groups commonly receive much media attention, peaceful and respectful everyday living in pluricultural Europe has become the norm. During the past few decades, most European societies have changed rapidly through cultural diversification, and recognition of and increasing openness towards various differences. Contemporary European societies have been perceived as 'super-diversified' (Vertovec 2007), in which diversity itself is broad, multidimensional, and fluid (Vertovec 2007; Blommaert and Rampton 2011), and characterized as 'complex' (Krauss 2011) when different positions - whether cultural, ethnic, national, social, 
religious, or linguistic - intersect. Fluid social ties, statuses, positions, and competences blur and complicate any simple categories or structures of diversity.

The increasing super-diversity of European societies normalizes intercultural dialogue as practice but also creates challenges for policy discourse. Policymakers need greater sensitivity to the complexities and fluidity included in today's diversity. This understanding should be reflected in the conceptual language used in their policy documentation.

\section{Locating Intercultural Dialogue Within Diversity Policies}

To support social and cultural well-being in diversified societies and to tackle the real or imagined problems, conflicts, and tensions that diversification may entail, societies have developed policies to govern diversity and initiatives, programmes, and projects to implement them in practice-with mixed results. The ERICart report surveyed diversity policies in 34 European countries in 2008. From their main policy approaches concerning majority-minority relations, the report identified a scale ranging from 'homogenization' to 'open intercultural dialogue' with intermediate steps of 'assimilation', 'cohesion-led integration', 'multiculturalism', 'diversityled integration', 'affirmative/positive action towards diversity', and 'intercultural encounters' (Wiesand et al. 2008, 89). According to the report, none of the surveyed countries could be clearly located in the category of 'open intercultural dialogue'.

The differences in diversity policies have been described with varying terms and concepts. There is no standard or single accepted definition for them, but their meanings vary between and within countries-and over time (see Mulcahy 2006; Barrett 2013, 17-19). One of the conceptual dimensions that are often used within these policies is the distinction between 'assimilation' and 'integration'. According to Barrett $(2013,24)$, “the term 'integration' denotes the incorporation of minority cultural groups into mainstream society through a two-way interaction process in which both cultural minorities and the cultural majority make accommodation to each other", while in assimilation "the accommodation is made only by cultural minorities". However, Meer and Modood (2013, 25) have noted how, in political discourse, the term 'assimilation' has often 
been replaced by 'integration', but this term has been given an assimilative interpretation.

Perhaps the most used terms within diversity policies - and the most debated conceptual pair-are multiculturalism and interculturalism. Multiculturalism is commonly described as "a shared commitment in multicultural society to recognise, maintain, and to accord respect and value to the different cultures that coexist within a territorially defined space" (Wiesand et al. 2008, 13). Although it includes many variances, it involves rejection of the idea that minorities should abandon their distinctive cultural beliefs and practices and assimilate into the dominant majority culture. Instead, multiculturalism sees that, by adjusting and adapting laws, rules, and regulations, societies should enable minorities to adhere to their own cultural practices (Kymlicka 1995, 2003; Barrett 2013, 16; Levrau and Loobuyck 2018).

At the end of the 2000s, European societies faced a 'backlash against multiculturalism' as many of the leading European politicians accused it of creating social problems and controversies between people rather than solving them (Bauböck 2008; Vertovec and Wessendorf 2010; Modood and Meer 2012; Barrett 2013). Also in scholarly debates, multiculturalism was criticized for encouraging members of different cultures to live separately in parallel communities without deeper interaction with and trust in one another, for emphasizing instead of blurring boundaries, and for focusing mainly on ethnic and national issues instead of the intersectional diversity in societies (e.g. Rodríguez-García 2010; Taylor 2012; Barrett 2013). The critics of multiculturalism have discussed contemporary intersectional diversities with the concept of interculturalism, emphasizing the importance of creating new opportunities across cultures and of supporting interaction between different cultural communities (Cantle 2013).

Several scholars have pointed out that the concepts and policy goals of multiculturalism and interculturalism are discursively fluid and that it is difficult to draw any clear or stable demarcation between the two (Levey 2012; Modood and Meer 2012; Wieviorka 2012; Taylor 2012; Barrett 2013; Meer and Modood 2013). As Modood and Meer (2012) and Modood (2017) have noted, the qualities that are often used to promote interculturalism (such as encouraging communication, recognition of dynamic identities, promotion of unity, and critique of illiberal cultural practice) are equally important (and on occasion foundational) features of multiculturalism. Some forms of the latter approach, which Parekh (2006) 
has called 'dialogical multiculturalism', particularly emphasize open and equal dialogue between cultural communities in multicultural societies.

Advocates of multiculturalism have also emphasized the politicization of the concept in public debates. On the one hand, the European attack on multiculturalism has been interpreted as stemming from the political failure to implement it in practice: multiculturalism has been blamed for certain phenomena of ghettoization and alienation of immigrants, instead of recognizing the political failures to promote integration and combat discrimination (Taylor 2012, 414). On the other hand, some scholars have noted how hostility to multiculturalism is mainly an exercise in avoiding the term rather than a retreat from implementing it: multiculturalist policies are still being implemented in most Western countries, although alongside new civic integration policies (Levrau and Loobuyck 2018). Moreover, scholars have pointed out how the whole discussion about the failure of multiculturalism and the need for new diversity policies has circled around the debates on Muslim communities in Western societies (Parekh 2008; Cantle 2013; Meer and Modood 2013). In fact, the policies promoting interculturalism have also been perceived to implicitly address the 'Muslim other' (Lähdesmäki and Wagener 2015). In both multiculturalism and interculturalism, the term 'culture' may hide explicit references to 'race', 'ethnicity', or 'religion' (see Bunjes 2013, 49) and, thus, include hierarchical power dynamics implicitly discussed with cultural terms.

Although the roots of the concept of interculturalism as a diversity policy reach back to the 1980s and 1990s (Portera 2008; Besley and Peters 2012; Cantle 2013), its growing use in policy discourse dates to the debate on the failure of multiculturalism. Interculturalism is often seen as built on the ideas of equality and non-discrimination. Critics note the 'failure' of multiculturalism to create cohesion among the different cultures living side by side (or in their own enclaves) in multicultural societies and have presented interculturalism as a solution to this. Interculturalism is located in a stronger emphasis on 'community cohesion'-in Cantle's (2001) terms -interaction, exchange, and dialogue (Cantle 2013; Barrett 2013, 26). It is, thus, seen as helping people to develop an understanding of different cultural beliefs and practices; fostering mutual understanding; increasing interpersonal trust, tolerance, and mutual respect; reducing prejudice and stereotypes; facilitating relationships between different communities; and fostering integration (Barrett 2013,26). As interculturalism stems from the critical view of multiculturalism and/or attempts to 
improve its shortcomings in practice, some scholars, such as Levrau and Loobuyck $(2018,7)$, have approached it "as a particular multicultural theory that has stressed some specific elements that other streams within the multicultural paradigm have somewhat neglected". The critics have, however, seen interculturalism as so fundamentally different from multiculturalism that they cannot be seen only as different emphases within the same diversity policy (Zapata-Barrero 2016, 2017).

A key to interculturalism is shared values-whether jointly developed in the interaction of communities or relying on commonly accepted 'universal values'. For example, the Council of Europe builds its interculturalism on "the universal values" of "respect for the equal dignity of all human beings, human rights, the rule of law and democratic principles", and "freedom of expression and other fundamental freedoms" (CofE 2008, 19). The idea of the universality of values as common ground for interculturalism is, however, problematic as values are never neutral or without a context. Even 'universal values', such as human rights and democracy, and the international organizations' interpretations of their meanings, can be seen as Western ideological constructions stemming from certain philosophical and political discussions in that part of the world (Panikkar 1982; Sharma 2006; Mouffe 2009). Bouchard $(2013,99)$ notes that "no state is culturally neutral" as no state refrains (or is able to refrain) from cultural interventions in favour of a certain group or a set of certain moral values seen as a 'good life' standard. Cherished societal norms and values are commonly defined by a culturally dominant group.

One of the core conceptual innovations closely related to interculturalism is intercultural dialogue. For Cantle $(2013,80)$, it is a practice or a process that is instrumental to implementing the aims of interculturalism, such as fostering understanding and empathy with others. It has also been seen as a "political strategy or instrument to promote cultural diversity or to foster social cohesion" (Wiesand et al. 2008, 4). Intercultural dialogue has been characterized as seeking to "develop a deeper understanding of diverse perspectives and practices; to increase participation and the freedom and ability to make choices; to foster equality; and to enhance creative processes" (Wiesand et al. 2008, xiii). The research dealing with intercultural dialogue has commonly emphasized its importance for democracy. Intercultural dialogue is perceived as a core skill to negotiate diverse backgrounds and viewpoints in a democratic society that is founded on the premise of inclusion of diverse viewpoints (see Papacharissi 2010, 38). It is also seen as founded on the 
critique of the essentialist notions of identity: intercultural dialogue is described as stipulating and fostering identities as transforming, plural, and fluid, as well as grounded on the idea of heterogeneity of all cultural and social groups (see Wilson 2013, 60). Moreover, the general view is that intercultural dialogue requires particular societal acts and settings, as well as creative abilities to encounter other people and to convert insights and challenges into innovation processes and new forms of expression (Wiesand et al. 2008, xiii).

One of the societal prerequisites commonly emphasized as key for intercultural dialogue is a 'shared space'-whether a physical space or a virtual environment (Wiesand et al. 2008, 10; Barrett 2013, 28; Wilson 2013,61 ). Relying on UNESCO's report, Our Creative Diversity (1996), shared space functions as an arena where new ideas and values can be publicly recognized in a dialogue. The ERICart report (Wiesand et al. 2008, 10) explains the idea of shared space as follows:

The main prerequisite to establish a dialogic climate is the attitude that no part/side/partner in the dialogue stays in the center of the world or in an absolute position. On the contrary, the 'center' must be emptied for the sake of dialogue in order for the majority-minority discourse to be overcome.

Moreover, intercultural dialogue has been seen as requiring particular skills and intercultural competencies, such as "open-mindedness, empathy, multiperspectivity, cognitive flexibility, communicative awareness, the ability to adapt one's behaviour to new cultural contexts, and linguistic, sociolinguistic and discourse skills including skills in managing breakdowns in communication" (Barrett 2013,26). These skills and competencies are considered important to learn at all levels of society. The formal education system, including schools, colleges, and universities, has a major role in these attempts (Barrett 2013, 27; Bunjes 2013, 49-50; Bouchard $2013,107)$. Some scholars have particularly emphasized empathy as a key skill for and practice of intercultural dialogue. For Houghton (2012), "intellectual empathy" means a bottom-up process and cognitive skill that necessitates the suspension of prior knowledge and values in favour of basing one's understanding only on the information provided by the interlocutor. As such, the practice of intellectual empathy results in a decentring (of one's own cultural positioning) that "seems to help reduce the resistance to the ideas of others" (Houghton 2012, 97). Houghton (2012, 98 ) mentions stereotypes as an example of the empathy-inhibiting force of 
pre-existing ideas and knowledge or frames. People often find it easier to empathize with others that are similar to them (Houghton 2012, 100).

Intercultural dialogue has been implemented in various ways in different sectors of society. Yet it is a challenge to produce a comprehensive comparative view of how it is implemented, as approaches to and understandings of the concept vary greatly in Europe (Eurobarometer 2007, 23). The ERICart report presents a survey of the implementation of intercultural dialogue in European countries, but emphasizes that its notions and practices are difficult to categorize due to the varying historical contexts, societal and political conditions, diversity structures, legal or political recognition of defined minority cultures and identities, and needs for social cohesion (Wiesand et al. 2008, 18-38). Due to this variety of contexts, the report claims that "one single model encompassing all national approaches to intercultural dialogue cannot realistically be expected, at present" (Wiesand et al. 2008, v).

The ERICart report also explored national education policy approaches to intercultural dialogue and perceived them as ranging from civic education (throughout Europe) to intercultural education, identified as a part of the general school curriculum in Austria, Belgium, Estonia, Ireland, Italy, Malta, the Netherlands, and the UK (Wiesand et al. 2008, vii, 41). According to the report, one of the main policy objectives for promoting dialogue across Europe was to provide resources for language learning (Wiesand et al. 2008, vii). Different takes on intercultural dialogue in the education sector are difficult to compare because of the divergent conceptual preferences for dealing with diversity. According to Hadjisoteriou et al. (2015), for instance, educators in Germany, Greece, and Ireland have preferred the terms interculturalism and intercultural education, while Britain and the Netherlands have historically worked with the concept of multiculturalism. The work of Koopmans and colleagues (2005, 2012 ) is equally indicative of the range of national policy-practice links, arguing that cross-national differences are shaped by historical legacies and have not become smaller over the past three decades.

Researchers in the DIALLS project who worked on European national education policy documentation from Cyprus, Finland, France, Germany, Israel, Lithuania, Portugal, Spain, and the UK found differences in conceptual approaches to cultural encounter, interaction, and dialogue (DIALLS 2018). In the surveyed education acts and curricula from these countries, intercultural dialogue was explicitly only briefly referred to in the data from Finland and Cyprus. The concept was used in the Finnish 
documents with reference to teaching and learning Sami culture, and in the Cypriot documents, in the context of communication, peaceful coexistence, cooperation, and solidarity between people in a multicultural society (DIALLS 2018, 81, 96).

\section{Critical Views of Intercultural Dialogue}

Besides agreeing with the importance of intercultural dialogue in superdiversified societies, scholars have expressed criticism of its implicit meaning and uses in policy discourses, as well as its implementation in practice. One common criticism is that intercultural dialogue alone is insufficient to tackle social, societal, and structural inequalities in super-diversified societies (Barrett 2013, 30). Critics have highlighted the need for concrete structural measures and economic resources to deliver them (Lähdesmäki and Wagener 2015, 27). Some critics have perceived intercultural dialogue as reducing cultural groups to separate and clearly identifiable units, although in super-diversified societies differences are intersectional and do not follow any clear demarcations (Barrett 2013, 30).

Most of the critical views of intercultural dialogue focus on structural power imbalances included in its policy rhetoric and implementation. For example, Lee (2016) has noted how the concept emphasizes talk over other means of expression and, thus, privileges those who have the capacity and 'voice' to speak. She showed how intercultural dialogue is itself an elitist construction available to those who can access it through education. Moreover, she pointed out how research on intercultural dialogue is dominated by Western scholarship as, irrespective of countries of origin, most scholars in the field have learned and internalized Western approaches to scholarship (Lee 2016, 240). Silvestri (2007, n.p.) has asked whether intercultural dialogue includes a "reference to the Western 'civilising mission' of the past" as the concept has been utilized in the European Union's attempts to promote European citizenship, belonging to Europe and to the Union, and a 'new European narrative' as its shared basis.

Previous research on diversity policies of the Council of Europe and European Union have identified various explicit and implicit power structures in the policy rhetoric on intercultural dialogue. Lähdesmäki and Wagener (2015) have criticized the Council of Europe's policy discourses on the concept for poorly recognizing the societal or historical differences between societies and for approaching diversity from a limited Western European perspective, narrowly emphasizing a Eurocentric understanding 
of cultures and cultural differences. The previous research on these European policy discourses on intercultural dialogue has also indicated that the concept includes power hierarchies between those who are expected to facilitate the dialogue and those expected to participate in it (Barrett 2013, 31; Lähdesmäki and Wagener 2015; Lähdesmäki et al. 2015), and how it implicitly consolidates differences between Europeans and their other-'we' and 'them' in the dialogue - rather than bringing subjects together (Aman 2012). Even though these policy discourses commonly seek to reach beyond the issues of migration and ethnic diversity to embrace other aspects of difference, the common subjects of the discourse have been perceived to be non-European, non-white, nonChristian, and non-educated migrants and ethnic groups (Lähdesmäki et al. 2015). The policy discourses could even unintentionally present the coexistence of distinct cultures as a problem and source of conflict, which is contradictory to the fundamental principle of intercultural dialogue as a policy and practice (Lähdesmäki and Wagener 2015; Lähdesmäki et al. 2015).

In general, the Council of Europe and European Union have been criticized for defining the concept of intercultural dialogue vaguely in their policy documents, or explaining it indistinctly and ambiguously (Näss 2010; Lähdesmäki et al. 2015). It is this conceptual vagueness that our book aims to clarify through in-depth concept analysis.

\section{REFERENCES}

Aman, R. 2012. The EU and the Recycling of Colonialism: Formation of Europeans Through Intercultural Dialogue. Educational Philosophy and Theory 44 (9): 1010-1023.

Barrett, M. 2013. Introduction: Interculturalism and Multiculturalism: Concepts and Controversies. In Interculturalism and Multiculturalism: Similarities and Differences, ed. M. Barrett, 15-42. Strasbourg: Council of Europe.

Bauböck, R. 2008. Beyond Culturalism and Statism: Liberal Responses to Diversity. EUROSPHERE Working Paper Series 6. https://EconPapers.repec.org/ RePEc:erp:ewpxxx:p0030.

Besley, T., and M.A. Peters. 2012. Interculturalism, Education and Dialogue. Bern: Peter Lang.

Betz, H.-G., and C. Johnson. 2004. Against the Current-Stemming the Tide: The Nostalgic Ideology of the Contemporary Radical Populist Right. Journal of Political Ideologies 9 (3): 311-327. 
Blommaert, J., and B. Rampton. 2011. Language and Superdiversity. Diversities $13(2): 1-21$.

Bouchard, G. 2013. Interculturalism: What Makes it Distinctive? In Interculturalism and Multiculturalism: Similarities and Differences, ed. M. Barrett, 93-110. Strasbourg: Council of Europe.

Brubaker, R. 2017. Between Nationalism and Civilizationism: The European Populist Moment in Comparative Perspective. Ethnic and Racial Studies 40 (8): 1191-1226.

Bunjes, U. 2013. The Intercultural Milestone: The History of the Council of Europe's White Paper on Intercultural Dialogue. In Interculturalism and Multiculturalism: Similarities and Differences, ed. M. Barrett, 43-52. Strasbourg: Council of Europe.

Cantle, T. 2001. Community Cohesion: A Report of the Independent Review Team. London: Home Office.

- 2013. Interculturalism as a New Narrative for the Era of Globalisation and Super-Diversity. In Interculturalism and Multiculturalism: Similarities and Differences, ed. M. Barrett, 69-92. Strasbourg: Council of Europe.

CofE (Council of Europe). 2008. White Paper on Intercultural Dialogue: "Living Together As Equals in Dignity”. Strasbourg: Council of Europe.

De Genova, N. 2018. The 'Migrant Crisis' as Racial Crisis: Do Black Lives Matter in Europe? Ethnic and Racial Studies 41 (10): 1765-1782.

DIALLS. 2018. Cultural Analysis Framework. https://dialls2020.eu/wp-content/uploads/2019/09/resubmitted-cultural-analysis-framework-with-coversheet-pdf.

EC (European Commission). 2017. Communication from the Commission to the European Parliament, the Council, the European Economic and Social Committee and the Committee of the Regions Strengthening European Identity Through Education and Culture. The European Commission's Contribution to the Leaders' Meeting in Gothenburg, November 17. COM (2017) 673 Final.

Eder, K. 2014. The EU in Search of Its People: The Birth of a Society Out of the Crisis of Europe. European Journal of Social Theory 17 (3): 219-237.

Eurobarometer. 2007. Special Eurobarometer 278: European Cultural Values. Brussels: European Commission.

Ganesh, S., and P. Holmes. 2011. Positioning Intercultural Dialogue: Theories, Pragmatics, and an Agenda. Journal of International and Intercultural Communication 4 (2): 81-86.

Gonçalves, S., and S. Majhanovich, eds. 2016. Art and Intercultural Dialogue. Rotterdam: Sense Publishers.

Hadjisoteriou, C., D. Faas, and P. Angelides. 2015. The Europeanisation of Intercultural Education? Responses from EU Policy-Makers. Educational Review 67 (2): 218-235.

Hellström, A. 2006. Bringing Europe Down to Earth. Lund: Lund University Press. 
Hoffmann, S. 1994. Europe's Identity Crisis Revisited. Daedalus 123 (2): 1-23. Hoskins, B., and M. Sallah. 2011. Developing Intercultural Competence in Europe: The Challenges. Language and Intercultural Communication 11 (2): 113-125.

Houghton, S.A. 2009. The Role of Intercultural Communicative Competence in the Development of World Englishes and Lingua Francas. Journal of Language, Linguistics and Literature 15: 69-95.

- 2012. Intercultural Dialogue in Practice: Managing Value Judgement Through Foreign Language Education. Bristol: Channel View Publications.

Jenkins, R. 2008. The Ambiguity of Europe. European Societies 10 (2): 153-176.

Kaya, A., and C. De Cesari. 2019. Introduction. In European Memory in Populism: Representations of Self and Other, ed. C. de Cesari and A. Kaya, 1-25. London: Routledge.

Koopmans, R., P. Statham, M. Giugni, and F. Passy. 2005. Contested Citizenship: Immigration and Cultural Diversity in Europe. Minneapolis: University of Minnesota Press.

Koopmans, R., I. Michalowski, and S. Waibel. 2012. Citizenship Rights for Immigrants: National Political Processes and Cross-National Convergence in Western Europe, 1980-2008. American Journal of Sociology 117 (4): 1202-1245.

Kowalczyk, J. 2011. The Immigration Problem' and European Education Reforms: From the Education of Migrants' Children to Intercultural Education. European Education 42 (4): 5-24.

Krauss, P. 2011. The Politics of Complex Diversity: A European Perspective. Ethnicities 12 (3): 3-25.

Kymlicka, W. 1995. Multicultural Citizenship: A Liberal Theory of Minority Rights. Oxford: Oxford University Press.

- 2003. Multicultural States and Intercultural Citizens. Theory and Research in Education 1 (2): 147-169.

Lähdesmäki, T. 2015. The Ambiguity of Europe and European Identity in Finnish Populist Political Discourse. Identities: Global Studies in Culture and Power 22 (1): 71-87.

- 2016. Politics of Tangibility, Intangibility, and Place in the Making of European Cultural Heritage in EU Heritage Policy. International Journal of Heritage Studies 22 (10): 766-780.

- 2019. European Culture, History, and Heritage as Political Tools in the Rhetoric of the Finns Party. In European Memory in Populism: Representations of Self and Other, ed. C. De Cesari and A. Kaya, 191-209. London: Routledge. Lähdesmäki, T., and A. Wagener. 2015. Discourses on Governing Diversity in Europe: Critical Analysis of the White Paper on Intercultural Dialogue. International Journal of Intercultural Relations 44: 13-28. 
Lähdesmäki, T., P.C.C.A. Heynderickx, A. Wagener, and S.M.F. Dieltjens. 2015. Negations and Negativity as Linguistic Devices in Policy Discourse of Intercultural Cities. Journal of Multicultural Discourses 10 (3): 332-348.

Lähdesmäki, T., V. Čeginskas, S. Kaasik-Krogerus, K. Mäkinen, and J. Turunen. 2020. Creating and Governing Cultural Heritage in the European Union: The European Heritage Label. London: Routledge. https://www.routledge.com/ Creating-and-Governing-Cultural-Heritage-in-the-European-Union-OpenAccess/Lahdesmaki-Ceginskas-Kaasik-Krogerus-Makinen-Turunen/p/ book/9780367148355.

Lee, E.L. 2016. Intercultural Dialogue in Theory and Practice: A Review. Journal of Multicultural Discourses 11 (2): 236-242.

Leikkilä, J., M. Faehnle, and M. Galanakis. 2013. Promoting Interculturalism by Planning of Urban Nature. Urban Forestry \& Urban Greening 12 (2): 183-190.

Levey, G.B. 2012. Interculturalism vs. Multiculturalism: A Distinction Without a Difference? Journal of Intercultural Studies 33 (2): 217-224.

Levrau, F., and P. Loobuyck. 2018. Introduction: Mapping the MulticulturalismInterculturalism Debate. Comparative Migration Studies 6 (13): 1-13.

Meer, N., and T. Modood. 2013. Interacting Interculturalism with Multiculturalism: Observations on Theory and Practice. In Interculturalism and Multiculturalism: Similarities and Differences, ed. M. Barrett, 111-132. Strasbourg: Council of Europe.

Modood, T. 2017. Must Interculturalists Misrepresent Multiculturalism? Comparative Migration Studies 5 (15): 1-17. https://doi.org/10.1186/ s40878-017-0058-y.

Modood, T., and N. Meer. 2012. How Does Interculturalism Contrast with Multiculturalism? Journal of Intercultural Studies 33 (2): 175-196.

Mouffe, C. 2009. Democracy in a Multipolar World. Millennium: Journal of International Studies 37 (3): 549-561.

Mudde, C. 2007. Populist Radical Right Parties in Europe. Cambridge: Cambridge University Press.

- 2017. Introduction to the Populist Radical Right. In The Populist Radical Right: A Reader, ed. C. Mudde, 1-10. London: Routledge.

Mulcahy, S. 2006. At the Borders of Europe: Ireland and Immigrant Integration from a Comparative European Perspective. In 6th Biennial Conference of ECSA-Canada: What Kind of Europe? Multiculturalism, Migration, Political Community and Lessons from Canada. Victoria, B.C. Canada, May 19-20.

Näss, H.E. 2010. The Ambiguities of Intercultural Dialogue: Critical Perspectives on the European Union's New Agenda for Culture. Journal of Intercultural Communication 23. https://www.immi.se/intercultural/nr23/nass.htm.

Norocel, O.C. 2013. Our People-A Tight-Knit Family Under the Same Protective Roof: A Critical Study of Gendered Conceptual Metaphors at Work in Radical Right Populism. Helsinki: University of Helsinki. 
O'Grady, K. 2010. Researching Religious Education Pedagogy Through an Action Research Community of Practice. British Journal of Religious Education 32 (2): 119-131.

Panikkar, R. 1982. Is the Notion of Human Rights a Western Concept? Diogenes 30 (120): 75-102.

Papacharissi, Z.A. 2010. A Private Sphere. Democracy in a Digital Age. Cambridge: Polity.

Parekh, B. 2006. Rethinking Multiculturalism: Cultural Diversity and Political Theory. Basingstoke: Palgrave Macmillan.

—. 2008. European Liberalism and 'The Muslim Question'. ISIM Paper 9. Leiden: Amsterdam University Press.

Portera, A. 2008. Intercultural Education in Europe: Epistemological and Semantic Aspects. Intercultural Education 19 (6): 481-491.

Rodríguez-García, D. 2010. Beyond Assimilation and Multiculturalism: A Critical Review of the Debate on Managing Diversity. Journal of International Migration and Integration 11 (3): 251-271.

Sandercock, L., and G. Attili. 2009. Where Strangers Become Neighbours: Integrating Immigrants in Vancouver, Canada. Berlin: Springer.

Sharma, A. 2006. Are Human Rights Western? A Contribution to the Dialogue of Civilizations. Oxford: Oxford University Press.

Silvestri, S. 2007. Policy Brief: Islam and the EU: The Merits and Risks of Intercultural Dialogue. Brussels: European Policy Centre.

Štrajn, D. 2018. The Intercultural Dialogue: Preparing Teachers for Diversity. International Review of Education 64 (3): 411-413.

Taylor, C. 2012. Interculturalism or Multiculturalism? Philosophy and Social Criticism 70 (4-5): 413-423.

UNESCO. 1996. Our Creative Diversity. Paris: UNESCO.

Vaughan-Williams, N. 2015. Europe's Border Crisis: Biopolitical Security and Beyond. Oxford: Oxford University Press.

Vertovec, S. 2007. New Complexities of Cohesion in Britain: Super-Diversity, Transnationalism and Civil-integration. Wetherby: Communities and Local Government Publications.

Vertovec, S., and S. Wessendorf. 2010. Introduction: Assessing the Backlash Against Multiculturalism. In The Multiculturalism Backlash: European Discourses, Policies and Practices, ed. S. Vertovec and S. Wessendorf, 1-31. New York: Routledge.

Wagener, A. 2012. Deconstructing Culture: Towards an Interactional Triad. Journal of Intercultural Communication 29. https://www.immi.se/intercultural/nr29/wagener.html.

Weiss, G. 2002. Searching for Europe: The Problem of Legitimisation and Representation in Recent Political Speeches on Europe. Journal of Language and Politics 1 (1): 59-83. 
Wiesand, A., I. Heiskanen, R. Mitchell, D. Cliché, M. Fisher, and L. Marsio. 2008. Sharing Diversity. National Approaches to Intercultural Dialogue in Europe. Bonn: European Institute for Comparative Cultural Research.

Wieviorka, M. 2012. Multiculturalism: A Concept to Be Redefined and Certainly Not Replaced by the Extremely Vague Term of Interculturalism. Journal of Intercultural Studies 33 (2): 225-231.

Wilk-Woś, Z. 2010. The Role of Intercultural Dialogue in the EU Policy. Journal of Intercultural Management 2 (1): 78-88.

Wilson, R. 2013. The Urgency of Intercultural Dialogue in a Europe of Insecurity. In Interculturalism and Multiculturalism: Similarities and Differences, ed. M. Barrett, 53-68. Strasbourg: Council of Europe.

Wodak, R. 2015. The Politics of Fear: What Right-Wing Populist Discourses Mean. London: Sage.

Wood, P., and C. Landry. 2008. The Intercultural City: Planning for Diversity Advantage. London: Earthscan.

Zapata-Barrero, R. 2016. Theorising Intercultural Citizenship. In Multiculturalism and Interculturalism: Debating the Dividing Lines, ed. N. Meer, T. Modood, and R. Zapata-Barrero, 53-76. Edinburgh: Edinburgh University Press.

- 2017. Interculturalism in the Post-Multicultural Debate: A Defence. Comparative Migration Studies 5 (1): 14. https://doi.org/10.1186/ s40878-017-0057-z.

Zay, D. 2011. A Cooperative School Model to Promote Intercultural Dialogue Between Citizens-to-Be. Policy Futures in Education 9 (1): 96-103.

Open Access This chapter is licensed under the terms of the Creative Commons Attribution 4.0 International License (http://creativecommons.org/licenses/ by $/ 4.0 /$ ), which permits use, sharing, adaptation, distribution and reproduction in any medium or format, as long as you give appropriate credit to the original author(s) and the source, provide a link to the Creative Commons licence and indicate if changes were made.

The images or other third party material in this chapter are included in the chapter's Creative Commons licence, unless indicated otherwise in a credit line to the material. If material is not included in the chapter's Creative Commons licence and your intended use is not permitted by statutory regulation or exceeds the permitted use, you will need to obtain permission directly from the copyright holder.

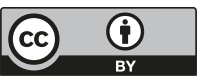

